\title{
Systematic Review \\ Quality of Life of Cancer Patients Receiving Enteral Nutrition: A Systematic Review of Randomized Controlled Trials
}

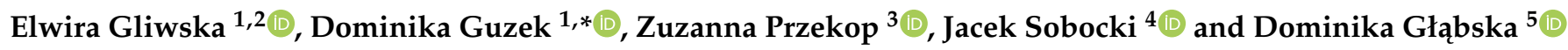 \\ 1 Department of Food Market and Consumer Research, Institute of Human Nutrition Sciences, \\ Warsaw University of Life Sciences (WULS-SGGW), 159C Nowoursynowska Street, 02-776 Warsaw, Poland; \\ elwira_gliwska@sggw.edu.pl \\ 2 Cancer Epidemiology and Primary Prevention Department, The Maria Sklodowska-Curie National Research \\ Institute of Oncology, 15B Wawelska Street, 02-034 Warsaw, Poland \\ 3 Department of Clinical Dietetics, Faculty of Health Sciences, Medical University of Warsaw, 27 Ciołka Street, \\ 01-445 Warsaw, Poland; zuzanna.przekop@wum.edu.pl \\ 4 Department of General Surgery and Clinical Nutrition, Centre of Postgraduate Medical Education in Warsaw, \\ 231 Czerniakowska Street, 00-416 Warsaw, Poland; jsobocki@mp.pl \\ 5 Department of Dietetics, Institute of Human Nutrition Sciences, Warsaw University of Life \\ Sciences (WULS-SGGW), 159C Nowoursynowska Street, 02-776 Warsaw, Poland; \\ dominika_glabska@sggw.edu.pl \\ * Correspondence: dominika_guzek@sggw.edu.pl; Tel.: +48-225-937-134
}

check for updates

Citation: Gliwska, E.; Guzek, D.; Przekop, Z.; Sobocki, J.; Głąbska, D. Quality of Life of Cancer Patients Receiving Enteral Nutrition: A Systematic Review of Randomized Controlled Trials. Nutrients 2021, 13, 4551. https://doi.org/10.3390/ nu13124551

Academic Editors: José J. Gaforio and Cristina Sanchez-Quesada

Received: 23 November 2021 Accepted: 15 December 2021 Published: 19 December 2021

Publisher's Note: MDPI stays neutral with regard to jurisdictional claims in published maps and institutional affiliations.

Copyright: (c) 2021 by the authors. Licensee MDPI, Basel, Switzerland. This article is an open access article distributed under the terms and conditions of the Creative Commons Attribution (CC BY) license (https:/ / creativecommons.org/licenses/by/ $4.0 /)$.
Abstract: Most studies confirm the beneficial effects of enteral nutrition on the quality of life, but some studies indicate an inverse association and its detrimental impacts. However, there are insufficient data on the effects of enteral nutrition on the quality of life of cancer patients. This systematic review aimed to describe the influence of applied enteral nutrition on the quality of life of cancer patients, based on the results of randomized controlled trials. It was registered in the PROSPERO database (CRD42021261226) and conducted based on the PRISMA guidelines. The searching procedure was conducted using the PubMed and Web of Science databases, as well as Cochrane Library, and it included studies published until June 2021. It was conducted to select randomized controlled trials assessing the influence of enteral nutrition (compared with the other model of nutrition) on the quality of life of cancer patients. A general number of 761 records were screened and a final number of 16 studies were included in the systematic review. The studies were included and assessed by two independent researchers, while the risk of bias was analyzed using the Newcastle-Ottawa Scale (NOS). Studies compared patients treated with and without enteral nutrition, patients treated with various methods of enteral nutrition or with enteral diets of various content, as well as patients treated with enteral and parenteral nutrition. Within the included studies, the majority were conducted in patients with cancers located in various parts of the body, or diverse areas within the gastrointestinal system, while some studies were conducted in specific populations of patients with a defined cancer location-esophagus, stomach, or ovary. The duration of applied enteral nutrition within the included studies was diversified-from two weeks or less to half a year or even more. The vast majority of studies used well-known and validated tools to assess the quality of life, either developed for a specific group of head/neck, esophagus/stomach, and ovary cancer patients or developed for more general patient populations. Most studies concerning patients treated with and without enteral nutrition supported applying enteral nutrition, which was concluded in seven studies out of ten (including four studies with a low risk of bias). The other important observations to be emphasized-formulated based on the studies with a low risk of bias-presented the role of oral supportive nutrition guided by a dietitian, as well as the beneficial role of enteral and parenteral nutrition, combined. In spite of a relatively low number of randomized controlled trials assessing the influence of enteral nutrition on the quality of life of cancer patients, which should be considered as a limitation, the results were promising. Most studies supported the positive influence of enteral nutrition on the quality of life, either assessed based on the psychological measures of the quality of life or by considering the other potential determinants (e.g., malnutrition, complications, etc.). Taking this into account, enteral nutrition should be applied whenever possible, both to prevent and treat 
malnutrition in cancer patients. However, considering the limited number of studies conducted so far, further research conducted in homogenic populations of patients is necessary.

Keywords: cancer; diet; nutrition; enteral nutrition; oncology; quality of life; QoL; randomized controlled trials

\section{Introduction}

Cancer is a growing global problem, being the first or second leading cause of death of individuals aged under 70 years in 112 of 183 countries, according to the World Health Organization (WHO) [1]. The Global Cancer Observatory (GCO) by the International Agency for Research on Cancer (IARC) and the WHO, within their GLOBOCAN 2020 estimates of incidence and mortality, indicated nearly 19.3 million new cancer cases and almost 10 million cancer deaths registered worldwide in 2020 [2]. Taking this into account, the WHO emphasizes that cancer is one of the main challenges for public health within both areas of prevention and treatment [3].

The cancer treatment methods are classified by the National Cancer Institute (NCI) as biomarker testing, chemotherapy, hormone therapy, immunotherapy, radiation therapy, stem cell transplant, surgery, and targeted therapy [4]. As indicated in the systematic review by Shrestha et al. [5], while choosing the therapeutic option, the length of life and quality of life are taken into consideration - patients with better health value rather than length of life over quality of life, and those with poorer physical status value rather than the quality of life over the length of life. The quality of life is defined as a sense of well-being and includes physical, psychological, social, and spiritual aspects, which may be changed in cancer patients [6]. The quality of life of cancer patients is significantly reduced [7-9], which results from the disease process itself-its course, symptoms and complications, the applied treatment, and the disease duration [10].

Among cancer symptoms and complications, malnutrition is one of the most common, as it results from anorexia and metabolic dysregulation combined, both caused by the tumor itself or by its treatment and contributing to cachexia [11]. It may affect up to $80 \%$ of cancer patients, while its prevalence depends on the cancer type, disease setting, comorbidities, and type of treatment performed [12]. Although the problem of malnutrition and cancer-related cachexia have been known for a long time, effective prevention and treatment remain a challenge [13]. Prevention and treatment are especially important as malnutrition not only affects the effectiveness of cancer treatment, as well as the prognosis and hospital stay length [14], but also influences the quality of life [15-17].

Taking this into consideration, the European Society for Clinical Nutrition and Metabolism (ESPEN), within its guidelines, indicated that the most important action against cancer-related malnutrition is to provide early screening and to assure individualized nutritional interventions [18]. An effective, personalized nutrition plan should include not only an appropriate diet or oral nutrition support but also enteral or parenteral nutrition if needed [19]. However, the recommendations by ESPEN indicate the superiority of feeding by the gastrointestinal tract over parenteral nutrition, and enteral nutrition is recommended if possible [20]. Similarly, the systematic review by Chow et al. [21] indicated that, for cancer patients, parenteral nutrition may result in an increased risk of complications compared with enteral nutrition but would not prolong survival.

However, there are insufficient data on the effects of enteral nutrition on the quality of life of cancer patients. A recent systematic review by Ojo et al. [22] assessed the effect of enteral tube feeding on the quality of life of various patients, including not only cancer patients but also those with other diseases and conditions. Based on this review, it was stated that most studies confirm the beneficial effect of enteral nutrition, but some studies indicate inverse association and its detrimental effects on the quality of life [22]. Taking this into account, the present systematic review aimed to describe the influence of applied 
enteral nutrition on the quality of life of cancer patients, based on the results of randomized controlled trials.

\section{Materials and Methods}

\subsection{The Systematic Review Design and Registration}

The systematic review of the influence of applied enteral nutrition on the quality of life in cancer patients was based on the Preferred Reporting Items for Systematic Reviews and Meta-Analyses (PRISMA) recommendations for the literature search and screening, including studies and reporting results [23]. The literature search was based on the PubMed and Web of Science databases, as well as Cochrane Library, and included studies published until June 2021.

The systematic review was registered in the International Prospective Register of Systematic Reviews (PROSPERO) database (CRD42021261226).

\subsection{The Inclusion and Exclusion Criteria}

The studies that were assessed within the present systematic review were intended to be randomized controlled trials assessing the influence of enteral nutrition (compared with the other model of nutrition) on the quality of life of cancer patients.

The inclusion criteria comprised research articles, presenting randomized controlled trials with full texts published in peer-reviewed journals in English, as well as the studied populations of cancer individuals with any enteral nutrition applied and quality of life assessed in any way.

The exclusion criteria comprised studies conducted in an animal model, studies not comparing enteral nutrition with any other model of nutrition but assessing technical aspects of enteral nutrition (such as the study by Patel et al. [24]), and studied populations of participants with any eating disorder (influencing the effectiveness of enteral nutrition applied) or intellectual disability (influencing the declared quality of life assessed within the studies).

While including the studies, no additional criteria associated with the type of cancer, characteristics of the studied population, or country were taken into account.

The summarized inclusion and exclusion criteria for the patient, intervention/exposure, comparator, outcome, and study design (PICOS) are presented in Table 1.

Table 1. The summarized inclusion and exclusion criteria for a patient, intervention/exposure, comparator, outcome, and study design (PICOS).

\begin{tabular}{lll}
\hline PICOS & Inclusion Criteria & Exclusion Criteria \\
\hline Population & Cancer patients & $\begin{array}{l}\text { Animal models; patients with } \\
\text { eating disorders or intellectual } \\
\text { disabilities }\end{array}$ \\
\hline Intervention/exposure & Enteral nutrition applied & $\begin{array}{l}\text { Enteral nutrition not described } \\
\text { within the study }\end{array}$ \\
\hline Comparison & $\begin{array}{l}\text { Influence of enteral nutrition } \\
\text { on the quality of life }\end{array}$ & $\begin{array}{l}\text { Lack of comparison of enteral } \\
\text { nutrition with the other model of } \\
\text { nutrition }\end{array}$ \\
\hline Outcome & Quality of life assessed & $\begin{array}{l}\text { Quality of life not presented within } \\
\text { the study }\end{array}$ \\
\hline Study design & Randomized controlled & $\begin{array}{l}\text { Articles not published in English, } \\
\text { not published in peer-reviewed } \\
\text { journals, retracted articles }\end{array}$ \\
\hline
\end{tabular}




\subsection{The Procedure of Systematic Review}

The electronic search was conducted within the PubMed and Web of Science databases, as well as Cochrane Central Register of Controlled Trials, and the detailed electronic search strategy is presented in Table 2.

Table 2. The detailed electronic search strategy applied within the systematic review for the PubMed and Web of Science databases, as well as Cochrane Central Register of Controlled Trials.

\begin{tabular}{|c|c|}
\hline Database/Register & Detailed Electronic Search Strategy \\
\hline PubMed & $\begin{array}{l}\text { ("cancer"[Title/Abstract] OR “tumor"[Title/Abstract] OR } \\
\text { "oncology"[Title/Abstract]) AND ("quality of life"[Title/Abstract] } \\
\text { OR “QoL"[Title/Abstract]) AND ("enteral"[Title/Abstract] OR } \\
\text { "enteric"[Title/Abstract] OR “intragastric"[Title/Abstract] OR } \\
\text { "intraintestinal"[Title/Abstract] OR "intestinal"[Title/Abstract] OR } \\
\text { "tube"[Title/Abstract]) AND ("nutrition"[Title/Abstract] OR } \\
\text { "feeding"[Title/Abstract]) }\end{array}$ \\
\hline Web of Science & $\begin{array}{l}\mathrm{AB}=(\text { cancer OR tumor OR oncology) } \mathrm{AND} A B=\text { (quality of life OR } \\
\mathrm{QoL}) \mathrm{AND} \mathrm{AB}=(\text { enteral OR enteric OR intragastric OR } \\
\text { intraintestinal OR intestinal OR tube) } \mathrm{AND} A B=\text { (nutrition OR } \\
\text { feeding) }\end{array}$ \\
\hline Cochrane Library & $\begin{array}{l}\text { ("cancer" OR “tumor" OR “oncology"):ti,ab,kw AND ("quality of } \\
\text { life" OR “QoL"):ti,ab,kw AND ("enteral" OR “enteric" OR } \\
\text { "intragastric" OR “intraintestinal" OR “intestinal" OR } \\
\text { "tube"):ti,ab,kw AND ("nutrition" OR “feeding"):ti,ab,kw }\end{array}$ \\
\hline
\end{tabular}

The procedure of identification, screening, and inclusion applied within the systematic review is presented in Figure 1. The identification of the eligible studies was performed independently by two researchers and conducted within three stages-based on the title, abstract, and full text of the study. The titles and abstracts were sourced from electronic databases, and full texts were also sourced from corresponding authors of studies if in electronic databases they were unavailable. If any disagreement appeared at any stage, it was consulted with the other researcher.

\subsection{The Procedure of Data Extraction}

Data extraction was performed independently by two researchers and if any disagreement appeared, it was consulted with the other researcher. If any information was unavailable within the study, it was obtained from the corresponding author of the study and, in such cases, it is referred to as data provided on request.

The extracted data comprised basic characteristics of the study (study design as defined within the article, the country with detailed location, and the time when the study was conducted), basic characteristics of the studied influence (nature of the studied group as defined within the study, disease location, and psychological measure for the assessed quality of life), basic characteristics of the studied group (the number of studied participants and female participants, age of the studied group, inclusion criteria, and exclusion criteria), basic characteristics of the applied nutritional intervention associated with enteral nutrition (applied enteral nutrition, duration of applied nutritional intervention, and any other information about nutrition as defined within the article), and the results and conclusions (the effect of the applied nutritional intervention on the quality of life).

The assessment of the risk of bias was conducted to define the methodological quality of the included studies [25] and the Newcastle-Ottawa Scale (NOS) [26] was used. The selection, comparability, and exposure/outcome were scored as follows: 0-4, 0-2, and 0-3 and, afterward, the total score was attributed to the categories of very high risk of bias (total score of 0-3), high risk of bias (total score of 4-6), and low risk of bias (total score of 7-9) [27]. 


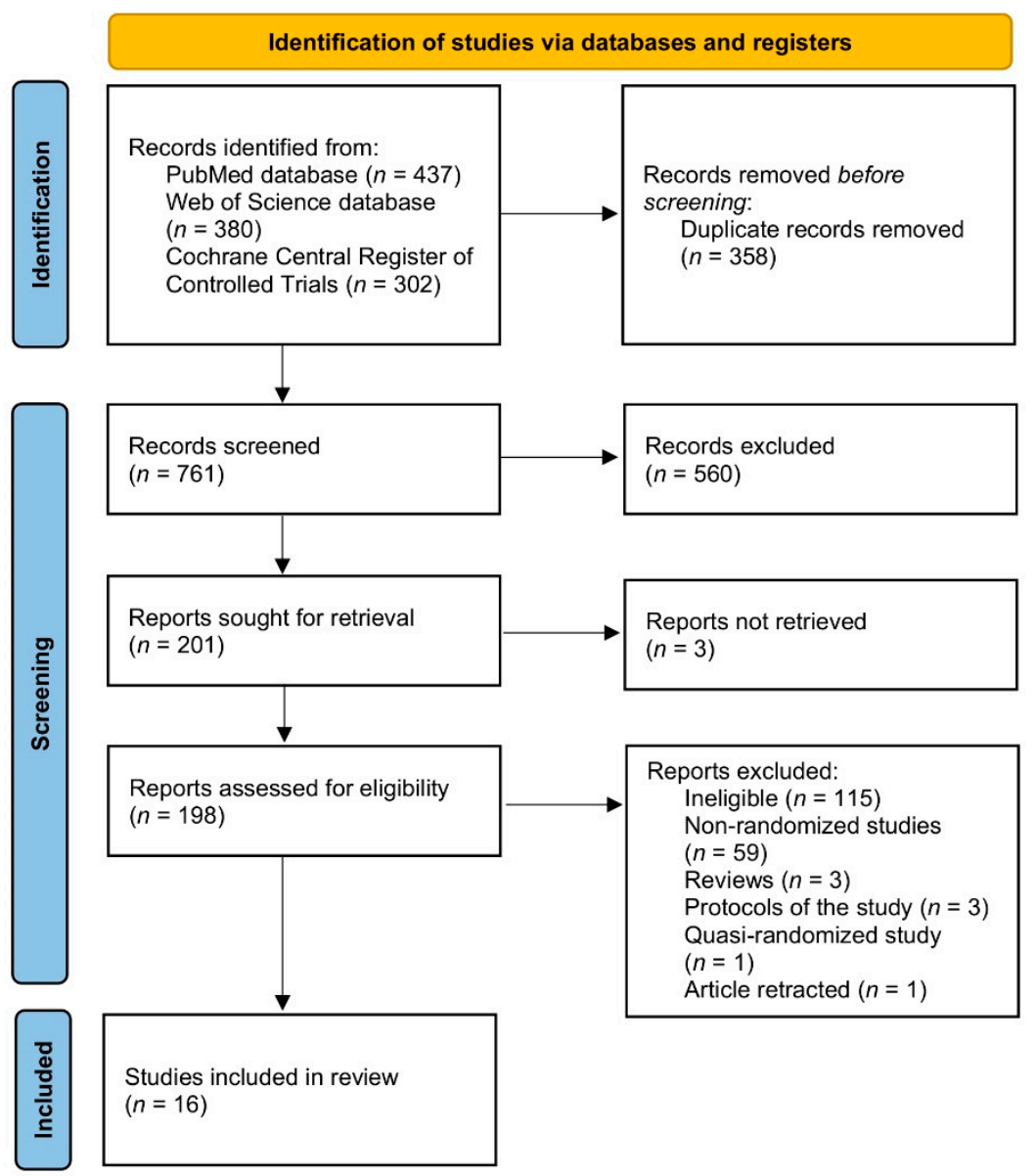

Figure 1. The procedure of identification, screening, and inclusion applied within the systematic review.

\section{Results}

The basic characteristics of the studies included in the systematic review [28-43] are presented in Table 3. Within the included studies, the majority were conducted in European countries-in Sweden [29,32-34], United Kingdom [35,39], Netherlands [28], Italy [38] and Poland [42] — but there were also some studies conducted in China [37,40,43] and Australia [36,41], which may have influenced various approaches applied to enteral nutrition. Most of the studies were conducted in the 2010s [31,35-41,43], but there were also some studies conducted in the 2000s [30-34,36,38] and even the 1990s [28].

Table 3. The basic characteristics of the studies included in the systematic review.

\begin{tabular}{lllll}
\hline Ref. & Authors, Year & Study Design & $\begin{array}{l}\text { Country/ } \\
\text { Detailed Location }\end{array}$ & Time \\
\hline$[28]$ & $\begin{array}{l}\text { van Bokhorst-de van der } \\
\text { Schueren et al., 2000 }\end{array}$ & Randomized clinical trial & Netherlands/Amsterdam & $1994-1997$ \\
\hline$[29]$ & Hyltander et al., 2005 & Randomized study & Sweden/Göteborg & Lack of data \\
\hline$[30]$ & Corry et al., 2008 & Randomized study & Lack of data & 2000-2002 \\
\hline$[31]$ & Sadasivan et al., 2012 & $\begin{array}{l}\text { Prospective, randomized, } \\
\text { controlled study }\end{array}$ & Lack of data & 2009-2011 \\
\hline$[32]$ & Silander et al., 2012 & Randomized study & Sweden/Göteborg & February 2002-December \\
\hline$[33]$ & Silander et al., 2013 & $\begin{array}{l}\text { Randomized longitudinal } \\
\text { study }\end{array}$ & Sweden/Göteborg & $\begin{array}{l}\text { February 2002-December } \\
\text { 2006 }\end{array}$ \\
\hline
\end{tabular}


Table 3. Cont.

\begin{tabular}{|c|c|c|c|c|}
\hline Ref. & Authors, Year & Study Design & $\begin{array}{l}\text { Country/ } \\
\text { Detailed Location }\end{array}$ & Time \\
\hline [34] & Axelsson et al., 2017 & $\begin{array}{l}\text { Randomized controlled } \\
\text { study }\end{array}$ & Sweden/Göteborg & 2002-2010 \\
\hline [35] & Bowrey et al., 2015 & Randomized controlled trial & $\begin{array}{l}\text { United } \\
\text { Kingdom/Leicester }\end{array}$ & July 2012-September 2014 \\
\hline [36] & Baker et al., 2015 & Randomized trial & Australia/Queensland & 2009-2013 \\
\hline [37] & Li et al., 2015 & Double blind placebo trial & China/Xinxiang & May 2012-May 2014 \\
\hline [38] & Gavazzi et al., 2016 & $\begin{array}{l}\text { Multicenter, controlled, } \\
\text { open-label, randomized } \\
\text { clinical trial }\end{array}$ & Italy/Milan & December 2008-June 2011 \\
\hline [39] & Froghi et al., 2017 & Randomized trial & $\begin{array}{l}\text { United } \\
\text { Kingdom/Devon }\end{array}$ & December 2012-July 2014 \\
\hline [40] & Wu et al., 2017 & $\begin{array}{l}\text { Open, randomized, } \\
\text { controlled trial }\end{array}$ & China/Shanghai & $\begin{array}{l}\text { Inclusion: July 2012-January } \\
2013\end{array}$ \\
\hline [41] & Brown et.al., 2017 & Randomized controlled trial & Australia/Queensland & September 2012-August 2016 \\
\hline [42] & $\begin{array}{l}\text { Kaźmierczak-Siedlecka et al., } \\
2020\end{array}$ & $\begin{array}{l}\text { Double-blind, randomized } \\
\text { placebo-controlled trial }\end{array}$ & Poland/Gdańsk & Lack of data \\
\hline [43] & Liu et al., 2020 & $\begin{array}{l}\text { A pilot parallel-group, } \\
\text { randomized single-blind, } \\
\text { clinical trial }\end{array}$ & China/Nanjing & Inclusion: January-June 2018 \\
\hline
\end{tabular}

The basic characteristics of the influence studied within the studies included in the systematic review are presented in Table 4 . The majority of the included studies were conducted in patients with cancers in various locations $[28,30-34,41,42]$ such as the esophagus [40,43], stomach [37], or ovary [36], or various locations within the gastrointestinal system $[29,35,38,39]$. Most of the studies presented populations recruited from a specific hospital/clinic/department [28,29,31,33,35,37,39-43] or a cancer registry [32,34,38], but for some studies, the specific clinic of origin was not defined [30,36]. The vast majority of studies used well-known and validated tools to assess the quality of life, either developed for a specific group of head/neck [31-34,41], esophagus/stomach [35,39], and ovarian cancer patients [36], or developed for more general populations of patients [28,29,32,34,36-43]. Only one study used a tool that was not previously validated and was developed based on other validated tools [30].

Table 4. The basic characteristics of the influence studied within the studies included in the systematic review.

\begin{tabular}{|c|c|c|c|}
\hline Ref. & Studied Group & Disease Location & Psychological Measure \\
\hline [28] & $\begin{array}{l}\text { Severely malnourished head and neck cancer } \\
\text { patients eligible for surgery from the } \\
\text { Department of Otolaryngology/Head and } \\
\text { Neck Surgery of the Vrije Universiteit, } \\
\text { Academic Hospital }\end{array}$ & $\begin{array}{l}\text { Oral cavity, oropharynx, hypopharynx, } \\
\text { larynx, other }\end{array}$ & $\begin{array}{l}\text { EORTC QLQ-C30; COOP-WONCA } \\
\text { charts }\end{array}$ \\
\hline [29] & $\begin{array}{l}\text { Upper gastrointestinal tract cancer patients } \\
\text { undergoing resections in Department of } \\
\text { Surgery at the Sahlgrenska University Hospital }\end{array}$ & Esophagus, stomach, pancreas & $\begin{array}{l}\text { Eating Dysfunction Scale; } \\
\text { Gastrointestinal Symptom Rating Scale; } \\
\text { PGWBI; } \\
\text { EORTC QLQ-C30 }\end{array}$ \\
\hline [30] & $\begin{array}{l}\text { Head and neck squamous cell carcinoma } \\
\text { patients }\end{array}$ & $\begin{array}{l}\text { Oral cavity, oropharynx, nasopharynx, } \\
\text { hypopharynx, larynx, other }\end{array}$ & $\begin{array}{l}\text { The non-validated questionnaire } \\
\text { developed based on EORTC } \\
\text { QLQ-H\&N35 }\end{array}$ \\
\hline [31] & $\begin{array}{l}\text { Head and neck cancer patients from the } \\
\text { Otorhinolaryngology Department }\end{array}$ & $\begin{array}{l}\text { Hypopharynx, larynx, nasopharynx, } \\
\text { oropharynx }\end{array}$ & EORTC QLQ-H\&N35 \\
\hline
\end{tabular}


Table 4. Cont.

\begin{tabular}{|c|c|c|c|}
\hline Ref. & Studied Group & Disease Location & Psychological Measure \\
\hline [32] & $\begin{array}{l}\text { Newly diagnosed advanced head and neck } \\
\text { cancer patients randomized at the Regional } \\
\text { Cancer Registry }\end{array}$ & $\begin{array}{l}\text { Oropharynx, oral cavity, hypopharynx, } \\
\text { nasopharynx, other }\end{array}$ & EORTC QLQ-C30; EORTC QLQ-H\&N35 \\
\hline [33] & $\begin{array}{l}\text { Newly diagnosed advanced head and neck } \\
\text { cancer patients in the Department of } \\
\text { Otorhinolaryngology-Head and Neck } \\
\text { Surgery at the Sahlgrenska University Hospital }\end{array}$ & Oral cavity, pharynx, neck lymph node & $\begin{array}{l}\text { EORTC QLQ-H\&N35-swallowing } \\
\text { sub-scale }\end{array}$ \\
\hline [34] & $\begin{array}{l}\text { Newly diagnosed advanced head and neck } \\
\text { cancer patients randomized at the Regional } \\
\text { Cancer Registry }\end{array}$ & $\begin{array}{l}\text { Oropharynx, oral cavity, hypopharynx, } \\
\text { nasopharynx, other }\end{array}$ & EORTC QLQ-C30; EORTC QLQ-H\&N35 \\
\hline [35] & $\begin{array}{l}\text { Esophageal or gastric cancer patients from } \\
\text { University Hospitals of Leicester NHS Trust } \\
\text { Oesophagogastric Cancer Service }\end{array}$ & Esophagus, stomach & $\begin{array}{l}\text { EORTC QLQ-C30; EORTC QLQ-OG25; } \\
\text { EQ-5D-3L }\end{array}$ \\
\hline [36] & Advanced epithelial ovarian cancer patients & Ovary & FACT-G; FACT-O; EQ-5D VAS; EQ-5D \\
\hline [37] & $\begin{array}{l}\text { Gastric cancer patients from the Department of } \\
\text { General Surgery, Xinxiang Central Hospital }\end{array}$ & Stomach & SF-36 \\
\hline [38] & $\begin{array}{l}\text { Upper gastrointestinal tract cancer patients } \\
\text { from Fondazione IRCCS Istituto Nazionale dei } \\
\text { Tumori and at the European Institute of } \\
\text { Oncology }\end{array}$ & $\begin{array}{l}\text { Esophagus, pancreas, stomach, biliary } \\
\text { tract }\end{array}$ & FAACT \\
\hline [39] & $\begin{array}{l}\text { Patients from Peninsula Oesophago-Gastric } \\
\text { Unit, Derriford Hospital undergoing upper } \\
\text { gastrointestinal surgery for cancer }\end{array}$ & Esophagus, stomach & MFI-20; EQ-5D; EORTC QLQ-OES18 \\
\hline [40] & $\begin{array}{l}\text { Esophageal cancer patients from the } \\
\text { Department of Thoracic Surgery of Zhongshan } \\
\text { Hospital }\end{array}$ & Esophagus & SF-36 \\
\hline [41] & $\begin{array}{l}\text { Head and neck cancer patients from Royal } \\
\text { Brisbane and Women's Hospital }\end{array}$ & $\begin{array}{l}\text { Oral cavity, oropharynx, nasopharynx, } \\
\text { hypopharynx, larynx, other }\end{array}$ & EORTC QLQ H\&N35; EORTC QLQ-C30 \\
\hline [42] & $\begin{array}{l}\text { Cancer patients from the Nutritional } \\
\text { Counselling Centre Copernicus in Gdansk and } \\
\text { the Department of Clinical Nutrition and } \\
\text { Dietetics from the Medical University of } \\
\text { Gdansk }\end{array}$ & $\begin{array}{l}\text { Cranium and face, gums, tongue, sinus, } \\
\text { throat, tonsil, esophagus, lung, stomach, } \\
\text { pancreas }\end{array}$ & WHOQOL-BREF \\
\hline [43] & $\begin{array}{l}\text { Patients who underwent enhanced recovery } \\
\text { after esophagectomy at the Department of } \\
\text { Cardiothoracic Surgery, Jinling Hospital }\end{array}$ & Esophagus & EORTC QLQ-C30 \\
\hline
\end{tabular}

COOP-WONCA, Dartmouth Primary Care Cooperative Information Project/World Organization of National Colleges, Academies, and Academic Associations of General Practice/Family Physicians; EORTC QLQ-C30, European Organization for the Research and Treatment of Cancer Quality of Life Questionnaire Instrument 30 items; EORTC QLQ-H\&N35, European Organization for the Research and Treatment of Cancer Quality of Life Questionnaire Instrument-Head and Neck 35 items; EORTC QLQ-OG25, European Organization for the Research and Treatment of Cancer Quality of Life Questionnaire-Oesophago-Gastric Disease-Specific Quality of Life Instrument 25 items; EQ-5D, EuroQol 5-Dimensional Scale; EQ-5D-3L, EuroQol 5-Dimensional Scale with three levels; EQ-5D VAS, EuroQol 5-Dimensional Visual Analogue Scale; FAACT, Self-Administrated Functional Assessment of Anorexia/Cachexia Therapy questionnaire; FACT-G, Functional Assessment of Cancer Therapy Scale-General; FACT-O, Functional Assessment of Cancer Therapy Scale-Ovarian; MFI-20, Multidimensional Fatigue Inventory 20 items; PGWBI, Psychological General Well-Being Index; QLQ-OES18, Esophagus Specific HealthRelated Quality of Life Questionnaire 18 items; SF-36, Short-Form-36 Health Survey; WHOQOL-BREF, World Health Organization Quality of Life assessment questionnaire-BREF.

The basic characteristics of the groups studied within the studies included in the systematic review are presented in Table 5. The included studies presented the observations formulated in a samples of various sizes - small samples of less than 50 participants $[28,30,35,39,42]$, medium-size samples of less than 100 participants [29,37,38,40,43], or large samples of 100 or more participants [31-34,36,41]. The age of the studied patients in most studies was about 60 years [28-30,32-37,39,41-43], but there were also some studies analyzing younger patients of less than 60 [40] or older patients of more than 60 years [38]. Within the inclusion criteria, the diagnosis of cancer was considered [28-43], but in some studies, it was accompanied by malnutrition $[28,30,36,38]$. 
Table 5. The basic characteristics of the groups studied within the studies included in the systematic review.

\begin{tabular}{cccc}
\hline Ref. & $\begin{array}{c}\text { No. of Participants } \\
\text { (Females) }\end{array}$ & $\begin{array}{c}\text { Age (Mean/Median } \\
\text { Years with SD/Range) }\end{array}$ & Inclusion and Exclusion Criteria \\
\hline
\end{tabular}

Inclusion: histologically proven squamous cell carcinoma of the oral cavity, larynx, oropharynx, or hypopharynx; preoperative weight loss $>10 \%$; required major ablative surgery and eligibility for surgery

[28] $31(15) \quad$ Mean of 56.6-61.4, Exclusion: received other investigational drugs or steroids; suffered from renal insufficiency, hepatic failure, any genetic immune disorders; confirmed diagnosis of acquired immunodeficiency syndrome (AIDS); lack of knowledge of the Dutch language

[29] $80(27) \quad \begin{aligned} & \text { Mean of 62-63, } \\ & \text { depending on group }\end{aligned}$

Inclusion: upper gastrointestinal tract cancer; major resective surgical procedures in the upper gastrointestinal tract Exclusion: impaired renal or hepatic function; disseminated malignant disease; ongoing corticosteroid treatment

[30] $\quad 33(9) \quad 60(46-80)$

Inclusion: head or neck cancer; radical (chemo)radiation treatment; patients defined as those who would probably require enteral feeding Exclusion: verified as those who did not require enteral feeding

Inclusion: stage 2 or stage 3 of squamous cell carcinoma of the head and

[31] $100(33) \quad$ Lack of data
neck; scheduled either for radical surgery with adjuvant radiotherapy (RT), chemo-RT, or for concurrent chemo- and radiation therapy Exclusion: patients with early-stage 2 of head and neck cancer

Inclusion: newly diagnosed, untreated, pharyngeal, or oral cancer, or malignant neck nodes with unknown primary in stage 3 or 4

[32] $134(43) \quad \begin{aligned} & \text { Mean of } 60-63, \\ & \text { depending on group }\end{aligned}$

Exclusion: treated with palliative intent; unable to answer quality of life questionnaires; not capable of following the study protocol; no possibility of having a percutaneous endoscopic gastrostomy (PEG) inserted due to previous abdominal surgery

Inclusion: newly diagnosed, oral, or pharyngeal cancer, or neck lymph [33] $127(39) \quad \begin{aligned} & \text { Mean of } 60-63, \\ & \text { depending on group }\end{aligned}$ node metastases with unknown primary in stage 3 or 4 Exclusion: palliative treatment; difficulties in following the protocol; participation in another clinical study

Inclusion: newly diagnosed, untreated, pharyngeal, or oral cancer, or malignant neck nodes with unknown primary in stage 3 or 4; patients surviving from [32]

[34] $134(43) \quad \begin{aligned} & \text { Mean of 60-63, } \\ & \text { depending on group }\end{aligned}$ Exclusion: treated with palliative intent; unable to answer quality of life questionnaires; not capable of following the study protocol; no possibility of having a percutaneous endoscopic gastrostomy (PEG) inserted due to previous abdominal surgery

Inclusion: confirmed diagnoses of esophageal or gastric cancer; elective
[35]
$41(5)$
$63.8 \pm 8.3$ * esophagectomy, or total gastrectomy with the placement of feeding jejunostomy tube Exclusion: undergoing subtotal gastrectomy

Inclusion: adult females; suspected or proven advanced epithelial ovarian cancer, primary peritoneal cancer, or fallopian tube cancer; required planned upfront or interval cytoreductive surgery; signs of moderate or severe malnutrition (Patient-Generated Subjective Global

[36] $109(109)$

Mean of 61.8-63.7, depending on group Assessment (PG-SGA) category B or C); medically fit for cytoreductive surgery

Exclusion: other cancers; recurrent epithelial ovarian cancer; contraindications to enteral feeding such as ileus, gastrointestinal ischemia, bilious or persistent vomiting, or mechanical obstruction; positive urine pregnancy test; unfit for surgery 
Table 5. Cont.

\begin{tabular}{ccc}
\hline Ref. & $\begin{array}{c}\text { No. of Participants } \\
\text { (Females) }\end{array}$ & $\begin{array}{c}\text { Age (Mean/Median } \\
\text { Years with SD/Range) }\end{array}$ \\
\hline
\end{tabular}

\section{Inclusion and Exclusion Criteria}

Inclusion: gastric cancer diagnoses confirmed by preoperative pathological study; no metastasis; no immunosuppressants and corticosteroid therapy within one month before surgery; transfusion therapy not used; blood loss $<400 \mathrm{~mL}$ during surgery

[37] $90(40) \quad 62.5 \pm 5.3$ Exclusion: history of hyperthyroidism, diabetes mellitus, and other metabolic diseases; dysfunction of heart, kidney, or liver; preoperative history of chemotherapy and radiotherapy; history of asthma and drug allergies; immune dysfunction or systemic infection; severe acid-base imbalance and water-electrolyte imbalance

Inclusion: adult; documented cancer of the upper gastrointestinal tract (esophagus, stomach, pancreas, biliary tract); candidate for major elective surgery; preoperative nutritional risk score $\geq 3$ (NRS 2002 tool) Exclusion: Karnofsky index $<60$; renal insufficiency (ongoing hemodialysis or plasma creatinine $>3 \mathrm{mg} / \mathrm{dl}$ ); respiratory insufficiency (arterial blood $\mathrm{PaO} 2<70 \mathrm{mmHg}$ ); American Society of Anaesthesiology score 4-5; ChildePugh liver function class $C$; short bowel syndrome; pregnancy; the need for emergency; palliative surgery; foreign residence; residents in an Italian region with no specific regulation for home enteral nutrition; unable to be regularly followed-up

depending on group

Inclusion: adult; patients undergoing upper gastrointestinal surgery for cancer; jejunostomy feed used postoperatively without complication Exclusion: participating in another trial; oral intake at hospital discharge of $>90 \%$ of requirements; if felt that they or their carers would not cope with home tube feeding; very low $\left(<18 \mathrm{~kg} / \mathrm{m}^{2}\right)$ or high $\left(>35 \mathrm{~kg} / \mathrm{m}^{2}\right)$ pre-operative Body Mass Index (BMI)

Inclusion: adults; scheduled esophagectomy for esophageal cancer Exclusion: age $>75$ years; Body Mass Index $(\mathrm{BMI})<18 \mathrm{~kg} / \mathrm{m}^{2}$; $\mathrm{BMI}>30 \mathrm{~kg} / \mathrm{m}^{2}$; contraindications for enteral nutrition or parenteral nutrition; preoperative initiation of enteral nutrition or parenteral nutrition; ongoing infections; preexisting organ failure (e.g., renal dysfunction required dialysis; non-compensatory chronic obstructive pulmonary disease); treatment with high doses of steroids; severe metabolic abnormalities (e.g., diabetes,

hyperthyroidism/hypothyroidism); chylothorax developed; could not tolerate programmed enteral feeding

Inclusion: adults; head or neck cancer; referred for a prophylactic gastrostomy before treatment

Exclusion: pregnancy; cognitively impaired; intellectual disability or mental illness; planned for non-curative intent treatment; diagnosed as severely or moderately malnourished with significant dysphagia requiring a liquid or pureed texture modified diet

Inclusion: adults; the presence of cancer; artificial access to the alimentary tract (nasogastric tube, gastrostomy, percutaneous endoscopic gastrostomy, jejunostomy, micro jejunostomy); qualification for home enteral nutrition

Exclusion: patients requiring home parenteral nutrition; not being able to attend the visit in the study center 
Table 5. Cont.

\begin{tabular}{|c|c|c|c|}
\hline Ref. & $\begin{array}{l}\text { No. of Participants } \\
\text { (Females) }\end{array}$ & $\begin{array}{l}\text { Age (Mean/Median } \\
\text { Years with SD/Range) }\end{array}$ & Inclusion and Exclusion Criteria \\
\hline [43] & $50(15)$ & $\begin{array}{l}\text { Mean of } 62.04-64.58 \\
\text { depending on group }\end{array}$ & $\begin{array}{l}\text { Inclusion: adults; referred electively for management of nonmetastatic } \\
\text { esophageal cancer } \\
\text { Exclusion: American Society of Anesthesiologists physical status classes } \\
4 \text { and 5; cardiac failure (New York Heart Association functional classes } \\
\text { III and IV); acute or unstable cardiac conditions (e.g., unstable angina or } \\
\text { symptomatic severe aortic stenosis); chronic obstructive pulmonary } \\
\text { disease (forced expiratory volume in the first second of expiration }<60 \% \\
\text { predicted); physical conditions that contraindicate exercise or oral } \\
\text { nutrition; inability to swallow; the presence of feeding jejunostomy; } \\
\text { end-stage kidney or liver disease; psychosis }\end{array}$ \\
\hline
\end{tabular}

* data provided on request.

The basic characteristics of the nutritional interventions associated with enteral nutrition applied within the studies included in the systematic review are presented in Table 6. The included studies compared patients treated with and without enteral nutrition $[28,32-36,38,39,41,43]$, patients treated with various methods of enteral nutrition $[30,31]$ or with enteral diets of various content [42], and patients treated with enteral and parenteral nutrition $[29,37,40]$. The duration of applied enteral nutrition within the included studies was diversified-from two weeks or less [28,40], through a few weeks or months $[30,31,35,36,38,39,42,43]$, to half a year or even more [29,32-34].

Table 6. The basic characteristics of the nutritional interventions associated with enteral nutrition applied within the studies included in the systematic review.

\begin{tabular}{|c|c|c|c|}
\hline Ref. & $\begin{array}{l}\text { Applied Enteral Nutrition (Studied Group/Studied } \\
\text { Groups/Control Group) }\end{array}$ & $\begin{array}{l}\text { Study Duration } \\
\text { (Enteral Nutrition) }\end{array}$ & Other Information about Nutrition \\
\hline [28] & $\begin{array}{l}\text { (1) no preoperative and standard postoperative } \\
\text { tube-feeding vs. (2) standard preoperative and } \\
\text { postoperative tube-feeding vs. ( } 3 \text { ) } \\
\text { arginine-supplemented preoperative and postoperative } \\
\text { tube-feeding ( } 41 \% \text { of casein proteins replaced by } \\
\text { arginine) }\end{array}$ & $\begin{array}{l}7-10 \text { days before } \\
\text { surgery and } 14 \text { days } \\
\text { after surgery }\end{array}$ & $\begin{array}{l}\text { Energy value of } 150 \% \text { of basal energy } \\
\text { expenditure }\end{array}$ \\
\hline [29] & $\begin{array}{l}\text { (1) postoperative oral supportive nutrition vs. (2) } \\
\text { specialized enteral nutrition (1000 kcal/day) vs. (3) } \\
\text { specialized parenteral nutrition ( } 900 \mathrm{kcal} / \text { day) }\end{array}$ & $\begin{array}{l}\text { Maximum } \\
12 \text { months after } \\
\text { surgery until the } \\
\text { preoperative weight } \\
\text { was reached }\end{array}$ & Oral supportive nutrition \\
\hline [30] & $\begin{array}{l}\text { (1) nasogastric (NG) tube feeding vs. ( } 2 \text { ) percutaneous } \\
\text { endoscopic gastrostomy (PEG) tube feeding }\end{array}$ & $\begin{array}{l}\text { (1) median of } 66 \text { days } \\
\text { (23-136 days) } \\
\text { (2) median of } \\
139 \text { days } \\
\text { (56-488 days) }\end{array}$ & $\begin{array}{l}\text { Energy value of } 50-100 \% \text { of energy } \\
\text { requirement (median of } 100 \% \text { ) }\end{array}$ \\
\hline [31] & $\begin{array}{l}\text { (1) percutaneous endoscopic gastrostomy (PEG) tube } \\
\text { feeding vs. (2) nasogastric (NG) tube feeding }\end{array}$ & 6 weeks & Lack of data \\
\hline [32] & $\begin{array}{l}\text { (1) tube feeding initiated if the oral intake became } \\
\text { inadequate ( }>1 \mathrm{~kg} \text { weight loss) vs. ( } 2 \text { ) standard care } \\
\text { (nutritional advice and enteral tube feeding when } \\
\text { necessary) }\end{array}$ & 24 months & $\begin{array}{l}\text { Energy value calculated as } 30 \mathrm{kcal} / \mathrm{kg} \\
\text { body weight/day and protein intake } \\
\text { need calculated as } 1.2-1.5 \mathrm{~g} / \mathrm{kg} \text { body } \\
\text { weight/day }\end{array}$ \\
\hline
\end{tabular}


Table 6. Cont.

\begin{tabular}{|c|c|c|c|}
\hline Ref. & $\begin{array}{l}\text { Applied Enteral Nutrition (Studied Group/Studied } \\
\text { Groups/Control Group) }\end{array}$ & $\begin{array}{l}\text { Study Duration } \\
\text { (Enteral Nutrition) }\end{array}$ & Other Information about Nutrition \\
\hline [33] & $\begin{array}{l}\text { (1) prophylactic percutaneous endoscopic gastrostomy } \\
\text { (PEG) - tube feeding initiated if the oral intake became } \\
\text { inadequate ( }>1 \mathrm{~kg} \text { weight loss) vs. (2) standard care } \\
\text { (nutritional advice and enteral tube feeding when } \\
\text { necessary) }\end{array}$ & 24 months & $\begin{array}{l}\text { Energy value calculated as } 30 \mathrm{kcal} / \mathrm{kg} \\
\text { body weight/day (for Body Mass Index } \\
(\mathrm{BMI})>25 \mathrm{~kg} / \mathrm{m}^{2} \text {-ideal weight for } \\
\text { BMI of } 25 \mathrm{~kg} / \mathrm{m}^{2} \text { used for calculation) } \\
\text { and protein intake need calculated as } \\
1.2-1.5 \mathrm{~g} / \mathrm{kg} \text { body weight/day }\end{array}$ \\
\hline [34] & $\begin{array}{l}\text { (1) tube feeding initiated if the oral intake became } \\
\text { inadequate ( }>1 \mathrm{~kg} \text { weight loss) vs. ( } 2 \text { ) standard care } \\
\text { (nutritional advice and enteral tube feeding when } \\
\text { necessary) }\end{array}$ & $\begin{array}{l}24 \text { months of study } \\
\text { as reported by [32], } \\
\text { followed-up after } 8 \\
\text { years }\end{array}$ & $\begin{array}{l}\text { Energy value calculated as } 30 \mathrm{kcal} / \mathrm{kg} \\
\text { body weight/day and protein intake } \\
\text { need calculated as } 1.2-1.5 \mathrm{~g} / \mathrm{kg} \text { body } \\
\text { weight } / \text { day }\end{array}$ \\
\hline [35] & $\begin{array}{l}\text { (1) overnight jejunostomy feeding via an electronic } \\
\text { pump vs. (2) routine clinical care (discontinuation of } \\
\text { jejunostomy feeds on the day of hospital discharge but } \\
\text { provided when necessary-if weight loss }>5 \% \text { from } \\
\text { baseline, reduced functional status, or estimated oral } \\
\text { calorie intake }<33 \% \text { of requirements) }\end{array}$ & 6 weeks & $\begin{array}{l}\text { Energy value and protein intake of } 50 \% \\
\text { of energy and protein requirement to be } \\
\text { provided by supplementary } \\
\text { jejunostomy; food fortification and the } \\
\text { use of prescribable nutritional } \\
\text { supplements for all patients }\end{array}$ \\
\hline
\end{tabular}

(1) nasojejunal tube feeding until the participant was

[36] able to maintain an adequate oral intake $(65-75 \%$ of daily nutritional requirements) vs. (2) standard diet

30 days Nasojejunal tube feeding with standard fiber-containing, high-protein enteral nutrition formula ( $20 \%$ protein, $30 \%$ fat, $50 \%$ carbohydrate) to provide $30 \mathrm{kcal} / \mathrm{kg}$ body weight/day

(1) Parenteral nutrition: $20 \mathrm{kcal} / \mathrm{kg}$ body weight/day, with nitrogen of $0.09-0.11 \mathrm{~g} / \mathrm{kg}$ body weight/day and non-protein calorie of $16-20 \mathrm{kcal} / \mathrm{kg}$

(1) Low-nitrogen and low-calorie parenteral combined with enteral nutrition and supplemented by targeted nursing intervention vs. (2) total parenteral nutrition

Lack of data body weight/day

(2) Total parenteral nutrition: 30-35 kcal/ kg body weight/day, with nitrogen of $0.19-0.21 \mathrm{~g} / \mathrm{kg}$ body weight/day and non-protein calorie of $28-32 \mathrm{kcal} / \mathrm{kg}$ body weight/day

(1) oral intake accompanied by home enteral nutrition (discontinuation of enteral nutrition after 2 months from discharge, if weight gain $\geq 5 \%$ was reported and oral

[38] diet was regular and adequate) vs. (2) oral intake only with oral nutritional supplements if needed (enteral nutrition allowed, but not before 2 months from discharge if a weight loss $\geq 5 \%$ was reported)

[39] (1) jejunal feeding vs. (2) no post-operative jejunal feeding after discharge

6 weeks

2 months

Energy value of enteral nutrition to cover basal energy requirement (12-20\% protein, $25-35 \%$ fat, $50-60 \%$ carbohydrate)

Jejunal feeding of $600 \mathrm{kcal} /$ day; both groups offered oral nutritional supplements to take at home

Both groups received parenteral minerals (potassium, phosphate, calcium, and magnesium), vitamins, and trace elements after surgery; parenteral calories from fat $(30 \%$ of

(1) enteral nutrition and supplementary parenteral

[40] nutrition (to meet energy requirements) vs. (2) enteral nutrition
9 days calories) and carbohydrates (70\%); target protein intake in the group receiving enteral nutrition and supplementary parenteral nutrition- $1.5 \mathrm{~g} / \mathrm{kg}$ fat-free mass/day; insulin continuously infused to maintain a blood glucose concentration $<10 \mathrm{mmol} / \mathrm{L}$ 
Table 6. Cont.

\begin{tabular}{|c|c|c|c|}
\hline Ref. & $\begin{array}{l}\text { Applied Enteral Nutrition (Studied Group/Studied } \\
\text { Groups/Control Group) }\end{array}$ & $\begin{array}{l}\text { Study Duration } \\
\text { (Enteral Nutrition) }\end{array}$ & Other Information about Nutrition \\
\hline [41] & $\begin{array}{l}\text { (1) enteral nutrition in addition to their current oral } \\
\text { intake immediately ( } 600 \mathrm{kcal} \text {-polymeric formula with } \\
\text { fiber and was increased as necessary) vs. (2) standard } \\
\text { nutrition with enteral nutrition only if necessary (oral } \\
\text { intake }<60 \% \text { of estimated energy requirements or } \\
\text { anticipated to be for }>10 \text { days, or the patient unable to } \\
\text { maintain weight, or the significant texture modification } \\
\text { of diet required, or increased or uncontrolled nutrition } \\
\text { impact symptoms) }\end{array}$ & Lack of data & $\begin{array}{l}\text { Both groups were encouraged to } \\
\text { maintain oral intake as much as } \\
\text { possible during treatment and as long } \\
\text { as it remained safe to do so }\end{array}$ \\
\hline [42] & $\begin{array}{l}\text { (1) standard enteral formula vs. (2) standard enteral } \\
\text { formula with Lactobacillus plantarum } 299 \mathrm{v}\end{array}$ & 4 weeks & $\begin{array}{l}\text { Standard normo-caloric enteral formula } \\
\text { without additional fiber }\end{array}$ \\
\hline [43] & $\begin{array}{l}\text { (1) enhanced nutrition support (additional nutrition } \\
\text { support via oral intake or jejunostomy tube: } 7 \\
\text { preoperative days-500-1000 kcal/day and after } \\
\text { discharge-500 kcal/day) vs. (2) conventional nutrition } \\
\text { (additional nutrition support via oral intake or } \\
\text { jejunostomy tube only if NRS2002 score } \geq 3 \text { during } 7 \\
\text { preoperative days-500-1000 kcal/day) }\end{array}$ & 1 month & $\begin{array}{l}\text { Both groups oral intake of semi-liquid } \\
\text { diet }\end{array}$ \\
\hline
\end{tabular}

The results and conclusions associated with the effect of the applied nutritional intervention on the quality of life within the studies included in the systematic review are presented in Table 7 . The results presented are based on the description formulated by authors of the studies within their abstracts.

Table 7. The results and conclusions associated with the effect of the applied nutritional intervention on the quality of life within the studies included in the systematic review.

$\begin{array}{lll}\text { Ref. } & \text { Observations } & \text { Conclusions }\end{array}$

Between baseline and the day before surgery, both preoperatively fed groups revealed a positive change for the dimensions of physical and emotional functioning and dyspnea (with significance in group II, $p=0.050,0.031,0.045$

[28] respectively). Group III showed a negative change in appetite $(p=0.049)$. Between baseline and 6 months after surgery, there were no differences between Group I and both pre-fed groups. There were no differences in favor of Group III compared to Group II.

Parenteral feeding was associated with the highest rate of

[29] nutrition-related complications, whereas enteral feeding reduced quality of life most extensively.

Enteral nutrition improves quality of life of severely malnourished head and neck cancer patients in the period preceding surgery. No benefit of preoperative enteral feeding on quality of life could be demonstrated 6 months after surgery.

Nutritional support with both tubes was good. There were no

[30] significant differences in patients' assessment of their overall quality of life.

There was a statistically significant difference between the two groups in patients' quality of life scores and complications.
After major surgery, specialized supportive enteral and parenteral nutrition are not superior to oral nutrition only when guided by a dietitian.

There is no evidence to support the routine use of percutaneous endoscopic gastrostomy tubes over nasogastric tube in the studied patient group.

Percutaneous endoscopic gastrostomy is more efficacious for quality of life than nasogastric tube as a channel for nutrition in advanced head and neck cancer patients over a short duration.

Prophylactic percutaneous endoscopic gastrostomy was associated with significantly earlier start and longer use of enteral nutrition, fewer malnourished patients over time, and improved quality of life at 6 months posttreatment start. 
Table 7. Cont.

\begin{tabular}{ll}
\hline Ref. & \multicolumn{1}{c}{ Observations } \\
\hline & $\begin{array}{l}\text { Both groups lost weight the first six months due to insufficient } \\
\text { energy intake and used enteral nutrition as their main intake } \\
\text { source; no significant differences between groups were found. } \\
\text { Problems with dysphagia were vast during the } 6 \text { months. Oral } \\
\text { intake was the major energy source after 1 year. }\end{array}$ \\
\hline [34] & $\begin{array}{l}\text { There was no significant difference in swallowing function } \\
\text { between the groups after 12 months, 24 months, and 8 years, } \\
\text { the oral intake scale, tube dependence, esophageal intervention, } \\
\text { and overall survival. }\end{array}$ \\
\hline [35] & $\begin{array}{l}\text { The global quality of life scores deteriorated in both groups } \\
\text { after surgery, but approached baseline levels in both groups by } \\
\text { six months. }\end{array}$ \\
\hline
\end{tabular}

[36] No significant difference in quality of life was found between the groups at any time point.

A low-nitrogen and low-calorie parenteral nutrition combined

[37] with enteral nutrition can effectively improve the postoperative quality of life.

After 2 months, patients on home enteral nutrition maintained their mean body weight, while patients in the nutritional

[38] counselling group showed a weight loss of $3.6 \mathrm{~kg}$. Patients
supported on home enteral nutrition had a higher chance to complete chemotherapy as planned ( $48 \%$ versus $34 \%$ ). Quality of life was not worsened by home enteral nutrition.

After hospital discharge, there were no differences in scores at any time point. From hospital discharge fatigue improved and plateaued at 6 weeks ( $p<0.05$ for both groups), independence at 12 weeks ( $p<0.05$ for both groups). No improvement was seen in quality of life until 24 weeks in the intervention group alone $(p<0.02)$ and not at all in the control group.

Scores for physical functioning $(71.5 \pm 24.3$ vs. $60.4 \pm 27.4$, $p<0.05)$ and energy/fatigue $(62.9 \pm 19.5$ vs. $54.2 \pm 23.5$, $p<0.05)$ were higher in the enteral + parenteral nutrition group 90 days following surgery.

[41] No differences were found for quality of life or clinical outcomes.

Head and neck cancer patients need nutritional support and enteral feeding for a long time period during and after treatment due to insufficient energy intake. A prophylactic percutaneous endoscopic gastrostomy did not significantly improve the enteral intake probably due to treatment side effects.

A prophylactic percutaneous endoscopic gastrostomy tube can be used without an increased risk of long-term dysphagia in patients with head and neck cancer.

The study demonstrated that home enteral feeding by jejunostomy was feasible, safe, and acceptable to patients and their carers.

Early enteral feeding did not significantly improve patients' quality of life compared to standard of care but may improve nutritional status.

A low-nitrogen and low-calorie parenteral nutrition combined with enteral nutrition can be suitable for clinical application.

The study lends support to the importance of home enteral nutrition in upper gastrointestinal cancer patients, after major surgery, as it helps maintain body weight without any safety concern or detrimental impact on quality of life.

Addition of jejunal feeding is effective in providing patients with an adequate energy intake. Increased energy intake however, produced no obvious improvement in measures of fatigue, quality of life or health economics.

Early use of supplemental parenteral nutrition to meet full calorie requirements of patients who underwent esophagectomy led to better quality of life 3 months after surgery.

The early intervention did not improve outcomes, but poor adherence to nutrition recommendations impacted on potential outcomes.

Lp299v may reduce the gastrointestinal symptoms related to enteral nutrition; notwithstanding, the improvement of quality of life may be the result of enteral nutrition rather than the effect of administration of Lp299v.

The improvement of quality of life was observed in both between the analyzed groups $(p>0.05)$.

This pilot study demonstrated that an enhanced

Enhanced nutritional support improved the quality of life of patients in physical function $(75.13 \pm 9.72$ vs. $68.33 \pm 7.68$,

$p=0.009)$ and fatigue symptom (42.27 \pm 9.93 vs. $49.07 \pm 11.33$, $p=0.028)$ compared to conventional nutritional support. nutritional support pathway including extended preoperative nutritional support and home enteral nutrition was feasible, safe, and might be beneficial to patients who underwent enhanced recovery after esophagectomy.

The summary of conclusions from the studies comparing patients treated with and without enteral nutrition included in the systematic review accompanied by the NewcastleOttawa Scale (NOS) score is presented in Table 8. It was stated that the majority of studies 
supported applying enteral nutrition, which was concluded in seven studies out of ten (including four studies of a low risk of bias). Although two of the supporting studies [32,34] were conducted within the same cohort, such observation is prominent.

The summary of conclusions from the studies comparing patients treated with enteral and parenteral nutrition, with various methods of enteral nutrition, and with enteral nutrition of various contents, included in the systematic review accompanied by the Newcastle-Ottawa Scale (NOS) score is presented in Table 9. The important conclusions that should be emphasized, formulated based on the studies of a low risk of bias, present the role of oral supportive nutrition guided by a dietitian [29], as well as the beneficial role of enteral and parenteral nutrition combined [40].

Table 8. The summary of conclusions from the studies comparing patients treated with and without enteral nutrition included to the systematic review accompanied by the Newcastle-Ottawa Scale (NOS) score.

\begin{tabular}{|c|c|c|c|c|c|}
\hline & \multicolumn{3}{|c|}{$\begin{array}{l}\text { Conclusion about Influence of Enteral } \\
\text { Nutrition on the General Quality of Life * }\end{array}$} & & $\begin{array}{l}\text { Quality of the Study Based } \\
\text { on the NOS Score ** }\end{array}$ \\
\hline [28] & \multicolumn{3}{|c|}{ Results supporting enteral nutrition } & Oral cavity & 7 \\
\hline$[32]^{* * *}$ & \multicolumn{3}{|c|}{ Results supporting enteral nutrition } & $\begin{array}{r}\text { Oropharyr } \\
\mathrm{n}\end{array}$ & 7 \\
\hline [33] & \multicolumn{3}{|c|}{ Results not supporting enteral nutrition } & Oral cavity & 7 \\
\hline$[34]^{* * *}$ & \multicolumn{3}{|c|}{ Results supporting enteral nutrition } & $\begin{array}{r}\text { Oropharyr } \\
\mathrm{n}\end{array}$ & 7 \\
\hline [35] & \multicolumn{3}{|c|}{ Inconclusive results } & & 6 \\
\hline [36] & \multicolumn{3}{|c|}{ Results supporting enteral nutrition } & & 7 \\
\hline [38] & \multicolumn{3}{|c|}{ Results supporting enteral nutrition } & Esophagu & 5 \\
\hline [39] & \multicolumn{3}{|c|}{ Results supporting enteral nutrition } & & 6 \\
\hline [41] & \multicolumn{3}{|c|}{ Results not supporting enteral nutrition } & $\begin{array}{r}\text { Oral cavity } \\
\text { hypo }\end{array}$ & 9 \\
\hline [43] & \multicolumn{3}{|c|}{ Results supporting enteral nutrition } & & 6 \\
\hline \multicolumn{6}{|c|}{$\begin{array}{l}\text { Table 9. The summary of conclusions from the studies comparing patients treated with enteral and parenteral nutrition, } \\
\text { with various methods of enteral nutrition, and with enteral nutrition of various contents, included in the systematic review } \\
\text { accompanied by the Newcastle-Ottawa Scale (NOS) score. }\end{array}$} \\
\hline \multicolumn{3}{|c|}{ Ref. } & \multicolumn{2}{|c|}{$\begin{array}{l}\text { Conclusion about Influence of } \\
\text { Enteral Nutrition on the } \\
\text { General Quality of Life }\end{array}$} & $\begin{array}{l}\text { Quality of the Study Based } \\
\text { on the NOS Score ** }\end{array}$ \\
\hline \multirow{3}{*}{\multicolumn{2}{|c|}{$\begin{array}{l}\text { Patients treated with } \\
\text { enteral and parenteral } \\
\text { nutrition }\end{array}$}} & [29] & $\begin{array}{l}\text { Specialized enteral/ } \\
\text { nutrition not superi } \\
\text { supervised oral sup } \\
\text { nutrition }\end{array}$ & $\begin{array}{l}\text { arenteral } \\
\text { to } \\
\text { ortive }\end{array}$ & 7 \\
\hline & & {$[37]$} & $\begin{array}{l}\text { Enteral + parenteral } \\
\text { superior to parenter }\end{array}$ & $\begin{array}{l}\text { hutrition } \\
\text { l nutrition }\end{array}$ & 4 \\
\hline & & {$[40]$} & $\begin{array}{l}\text { Enteral + parenteral } \\
\text { superior to enteral }\end{array}$ & $\begin{array}{l}\text { lutrition } \\
\text { atrition }\end{array}$ & 7 \\
\hline
\end{tabular}


Table 9. Cont.

\begin{tabular}{|c|c|c|c|c|}
\hline \multirow{2}{*}{$\begin{array}{l}\text { Patients treated with } \\
\text { various methods of } \\
\text { enteral nutrition }\end{array}$} & [30] & $\begin{array}{l}\text { Percutaneous Endoscopic } \\
\text { Gastrostomy and Nasogastric } \\
\text { Tube-comparable }\end{array}$ & $\begin{array}{c}\text { Oral cavity, } \\
\text { oropharynx, } \\
\text { nasopharynx, } \\
\text { hypopharynx, larynx, } \\
\text { other }\end{array}$ & 5 \\
\hline & [31] & $\begin{array}{l}\text { Percutaneous Endoscopic } \\
\text { Gastrostomy superior to } \\
\text { Nasogastric Tube }\end{array}$ & $\begin{array}{l}\text { Hypopharynx, larynx, } \\
\text { nasopharynx, } \\
\text { oropharynx }\end{array}$ & 6 \\
\hline $\begin{array}{l}\text { Patients treated with } \\
\text { enteral nutrition of } \\
\text { various content }\end{array}$ & [42] & $\begin{array}{l}\text { No effect of including Lp299v to } \\
\text { enteral nutrition }\end{array}$ & $\begin{array}{l}\text { Cranium \& face, gums, } \\
\text { tongue, sinus, throat, } \\
\text { tonsil, esophagus, lung, } \\
\text { stomach, pancreas }\end{array}$ & 6 \\
\hline
\end{tabular}

* in case of no influence on the psychological measures of the quality of life, its influencing factors are taken into account (e.g., malnutrition, complications, etc.); ${ }^{* *}$ total score of: 0-3-very high risk of bias, 4-6-high risk of bias, 7-9-low risk of bias.

\section{Discussion}

Due to an increase in the effectiveness of anti-cancer treatment [44] and an increase in life expectancy in cancer patients [45], the long-term complications will probably be observed more often, resulting in increasing role of the quality of life [46]. Taking this into account, it must be emphasized that the systematic review by Lis et al. [47], assessing the role of nutritional status in predicting quality of life in cancer individuals, indicated that correcting malnutrition may improve quality of life in cancer patients. Considering this, the presented systematic review is based on the assumption that enteral nutrition may promote a better nutritional status.

In agreement with the indicated association between nutritional status and quality of life, the ESPEN, within its recent practical guidelines [48] recommended applying nutritional support, including dietary advice, oral nutrition supplements, and enteral and parenteral nutrition as an effective way of improving nutritional status and malnutrition prevention. However, while choosing the method of nutritional support, it is indicated that, despite nutritional interventions, enteral nutrition should be recommended if oral nutrition remains inadequate, and parenteral nutrition should be recommended if enteral nutrition is not sufficient or feasible [48].

The results of the conducted systematic review of the randomized controlled trials confirmed the beneficial effects of enteral nutrition for cancer patients in the area of quality of life. While comparing patients treated with and without enteral nutrition, it was stated that enteral nutrition has a beneficial effect on the quality of life in a majority of studies, confirmed in groups of head and neck cancer patients [28,32,34], upper gastrointestinal tract cancer patients $[38,39,43]$, and ovarian cancer patients [36]. At the same time, the results were not so consistent while comparing patients treated with enteral and parenteral nutrition; depending on the study, the various results were observed [29,37,40], but generally combined enteral and parenteral nutrition was stated to be superior to both enteral [40] and parenteral nutrition alone [37]. The indicated observations are in agreement with the recommendations by ESPEN [48], indicating the need to meet the energy requirements of patients, which must be considered the overall objective.

In spite of the fact that the majority of included studies concluded the beneficial role of enteral nutrition (especially while compared with no nutritional support), some disadvantages or contradictory results are also indicated. Such observations were formulated mainly within studies assessing the effect of prophylactic enteral nutrition, applied, not when necessary, but earlier, in order to limit the risk of malnutrition $[33,35,41]$. This may result from the fact that the enteral nutrition procedure itself can generate complications [49]. As such complications may indirectly affect the quality of life, each of them needs to be considered while choosing the best option for nutritional support.

While describing the results gathered within randomized controlled trials, it should be emphasized that only a small number of such studies have been conducted so far, while 
various methods of enteral nutrition and various nutritional values of diet have been studied. The various studies comparing patients treated with and without enteral nutrition and comparing patients treated with enteral and parenteral nutrition are incomparable due to various enteral nutrition procedures applied within the studies. At the same time, only two randomized controlled trials comparing patients treated with various methods of enteral nutrition $[30,31]$, and one comparing patients treated with enteral nutrition of various contents [42], have been conducted so far, so no deeper conclusions can be made, especially if the results of the studies are contradictory [30,31].

The other problem while comparing the results of the included studies is associated with various cancer locations in the included studies, but also with the well-known diverse cancer course and intra-patient variability observed in the treatment effectiveness [50]. As a result, gathering and combining results observed within various studies may be impossible.

Despite the described difficulties in synthesizing results of the included studies, the most prominent observation formulated within the majority of studies remains consistent and is associated with the positive influence of enteral nutrition on the quality of life. While the quality of life is linked to the stage of cancer [51], the prognosis [52], malnutrition [53], and applied therapy [54], enteral nutrition must also be taken into account as a factor indirectly affecting it by improving the effectiveness of cancer therapy [55] and reducing the risk of malnutrition [56].

Considering the described results of gathered randomized controlled trials, and in agreement with the ESPEN guidelines, enteral nutrition should be applied whenever possible to improve the quality of life of cancer patients.

\section{Conclusions}

Most of the studies support the positive influence of enteral nutrition on the quality of life, either assessed based on the psychological measures of the quality of life or by considering the other potential determinants (e.g., malnutrition, complications, etc.). Taking this into account, enteral nutrition should be applied whenever possible, both to prevent and treat malnutrition in cancer patients. However, considering the limited number of studies conducted so far, further research conducted in homogenic populations of patients is necessary.

Author Contributions: Conceptualization, E.G., D.G. (Dominika Guzek), and D.G. (Dominika Głąbska); methodology, E.G., D.G. (Dominika Guzek), and D.G. (Dominika Glabska); formal analysis, E.G., D.G. (Dominika Guzek), Z.P., and D.G. (Dominika Głąbska); investigation, E.G., D.G. (Dominika Guzek), Z.P., and D.G. (Dominika Głabska); writing—original draft preparation, E.G., D.G. (Dominika Guzek), Z.P., J.S., and D.G. (Dominika Głabska); writing—review and editing, E.G., D.G. (Dominika Guzek), Z.P., J.S., and D.G. (Dominika Głąbska). All authors have read and agreed to the published version of the manuscript.

Funding: This research was funded by the Polish Ministry of Science and Higher Education within funds of the Institute of Human Nutrition Sciences, Warsaw University of Life Sciences (WULS), for scientific research.

Institutional Review Board Statement: The literature search was conducted according to the guidelines of the Preferred Reporting Items for Systematic Reviews and Meta-Analyses (PRISMA) and the review was registered in the International Prospective Register of Systematic Reviews (PROSPERO) database (CRD42021261226).

Informed Consent Statement: Not applicable.

Conflicts of Interest: The authors declare no conflict of interest.

\section{References}

1. World Health Organizations (WHO). Cause-Specific Mortality, 2000-2019. Available online: https:/ /www.who.int/data/gho/ data/themes/mortality-and-global-health-estimates/ghe-leading-causes-of-death (accessed on 5 November 2021).

2. Sung, H.; Ferlay, J.; Siegel, R.L.; Laversanne, M.; Soerjomataram, I.; Jemal, A.; Bray, F. Global cancer statistics 2020: GLOBOCAN estimates of incidence and mortality worldwide for 36 cancers in 185 countries. CA Cancer J. Clin. 2021, 1, 209-249. [CrossRef] 
3. World Health Organizations (WHO). Cancer. Available online: https://www.who.int/health-topics/cancer\#tab=tab_1 (accessed on 5 November 2021).

4. National Institute of Health (NIH); National Cancer Institute (NIC). Types of Cancer Treatment. Available online: https: //www.cancer.gov/about-cancer/treatment/types (accessed on 5 November 2021).

5. Shrestha, A.; Martin, C.; Burton, M.; Walters, S.; Collins, K.; Wyld, L. Quality of life versus length of life considerations in cancer patients: A systematic literature review. Psychooncology 2019, 28, 1367-1380. [CrossRef] [PubMed]

6. Jitender, S.; Mahajan, R.; Rathore, V.; Choudhary, R. Quality of life of cancer patients. J. Exp. Ther. Oncol. 2018, 12, 217-221. [PubMed]

7. Nayak, M.G.; George, A.; Vidyasagar, M.S.; Mathew, S.; Nayak, S.; Nayak, B.S.; Shashidhara, Y.N.; Kamath, A. Quality of Life among Cancer Patients. Indian J. Palliat. Care 2017, 23, 445-450. [CrossRef]

8. Abdollahzadeh, F.; Sadat Aghahossini, S.; Rahmani, A.; Asvadi Kermani, I. Quality of life in cancer patients and its related factors. J. Caring. Sci. 2012, 1, 109-114. [CrossRef] [PubMed]

9. Binotto, M.; Reinert, T.; Werutsky, G.; Zaffaroni, F.; Schwartsmann, G. Health-related quality of life before and during chemotherapy in patients with early-stage breast cancer. Ecancermedicalscience 2020, 14, 1007. [CrossRef] [PubMed]

10. Lewandowska, A.; Rudzki, G.; Lewandowski, T.; Próchnicki, M.; Rudzki, S.; Laskowska, B.; Brudniak, J. Quality of Life of Cancer Patients Treated with Chemotherapy. Int. J. Environ. Res. Public Health 2020, 17, 6938. [CrossRef] [PubMed]

11. Muscaritoli, M.; Corsaro, E.; Molfino, A. Awareness of Cancer-Related Malnutrition and Its Management: Analysis of the Results From a Survey Conducted Among Medical Oncologists. Front. Oncol. 2021, 11, 682999. [CrossRef]

12. Bossi, P.; Delrio, P.; Mascheroni, A.; Zanetti, M. The Spectrum of Malnutrition/Cachexia/Sarcopenia in Oncology According to Different Cancer Types and Settings: A Narrative Review. Nutrients 2021, 13, 1980. [CrossRef] [PubMed]

13. Baracos, V.E. Cancer-associated malnutrition. Eur. J. Clin. Nutr. 2018, 72, 1255-1259. [CrossRef]

14. Kim, D.H. Nutritional issues in patients with cancer. Intest. Res. 2019, 17, 455-462. [CrossRef] [PubMed]

15. Polański, J.; Jankowska-Polańska, B.; Mazur, G. Relationship Between Nutritional Status and Quality of Life in Patients with Lung Cancer. Cancer Manag. Res. 2021, 13, 1407-1416. [CrossRef]

16. Rios, T.C.; de Oliveira, L.P.M.; da Costa, M.L.V.; da Silva Baqueiro Boulhosa, R.S.; Roriz, A.K.C.; Ramos, L.B.; Bueno, A.A. A poorer nutritional status impacts quality of life in a sample population of elderly cancer patients. Health Qual. Life Outcomes 2021, 19, 90. [CrossRef] [PubMed]

17. Sonneborn-Papakostopoulos, M.; Dubois, C.; Mathies, V.; Heß, M.; Erickson, N.; Ernst, T.; Huebner, J. Quality of life, symptoms and dietary habits in oncology outpatients with malnutrition: A cross-sectional study. Med. Oncol. 2021, 38, 20. [CrossRef]

18. Arends, J.; Baracos, V.; Bertz, H.; Bozzetti, F.; Calder, P.C.; Deutz, N.E.P.; Erickson, N.; Laviano, A.; Lisanti, M.P.; Lobo, D.N.; et al. ESPEN expert group recommendations for action against cancer-related malnutrition. Clin. Nutr. 2017, 36, 1187-1196. [CrossRef]

19. Cotogni, P. Enteral versus parenteral nutrition in cancer patients: Evidences and controversies. Ann. Palliat. Med. 2016, 5, 42-49. [CrossRef] [PubMed]

20. Bischoff, S.C.; Austin, P.; Boeykens, K.; Chourdakis, M.; Cuerda, C.; Jonkers-Schuitema, C.; Lichota, M.; Nyulasi, I.; Schneider, S.M.; Stanga, Z.; et al. ESPEN guideline on home enteral nutrition. Clin. Nutr. 2020, 39, 5-22. [CrossRef]

21. Chow, R.; Bruera, E.; Chiu, L.; Chow, S.; Chiu, N.; Lam, H.; McDonald, R.; DeAngelis, C.; Vuong, S.; Ganesh, V.; et al. Enteral and parenteral nutrition in cancer patients: A systematic review and meta-analysis. Ann. Palliat. Med. 2016, 5, 30-41. [CrossRef]

22. Ojo, O.; Keaveney, E.; Wang, X.-H.; Feng, P. The Effect of Enteral Tube Feeding on Patients' Health-Related Quality of Life: A Systematic Review. Nutrients 2019, 11, 1046. [CrossRef] [PubMed]

23. Moher, D.; Liberati, A.; Tetzlaff, J.; Altman, D.G.; PRISMA Group. Preferred reporting items for systematic reviews and meta-analyses: The PRISMA statement. PLoS Med. 2009, 6, e1000097. [CrossRef] [PubMed]

24. Patel, N.R.; Bailey, S.; Tai, E.; Mirrahimi, A.; Mafeld, S.; Beecroft, J.R.; Tan, K.T.; Annamalai, G. Randomized Controlled Trial of Percutaneous Radiologic Gastrostomy Performed With and Without Gastropexy: Technical Success, Patient-Reported Outcomes and Safety. Cardiovasc. Intervent. Radiol. 2021, 44, 1081-1088. [CrossRef]

25. Assessing Risk of Bias in Non-Randomized Studies. Chapter 13.5.2.3. Available online: http://handbook-5-1.cochrane.org/ (accessed on 16 November 2021).

26. Wells, G.A.; Shea, B.; O'Connell, D.; Peterson, J.; Welch, V.; Losos, M.; Tugwell, P. The Newcastle-Ottawa Scale (NOS) for Assessing the Quality of Nonrandomised Studies in Meta-Analyses. Available online: http://www.ohri.ca/programs/clinical_ epidemiology/oxford.asp (accessed on 16 November 2021).

27. You, S.; Kong, T.H.; Han, W. The Effects of short-term and long-term hearing changes on music exposure: A systematic review and meta-analysis. Int. J. Environ. Res. Public Health 2020, 17, 2091. [CrossRef]

28. Van Bokhorst-de Van der Schuer, M.A.; Langendoen, S.I.; Vondeling, H.; Kuik, D.J.; Quak, J.J.; Van Leeuwen, P.A. Perioperative enteral nutrition and quality of life of severely malnourished head and neck cancer patients: A randomized clinical trial. Clin. Nutr. 2000, 19, 437-444. [CrossRef] [PubMed]

29. Hyltander, A.; Bosaeus, I.; Svedlund, J.; Liedman, B.; Hugosson, I.; Wallengren, O.; Olsson, U.; Johnsson, E.; Kostic, S.; Henningsson, A.; et al. Supportive nutrition on recovery of metabolism, nutritional state, health-related quality of life, and exercise capacity after major surgery: A randomized study. Clin. Gastroenterol. Hepatol. 2005, 3, 466-474. [CrossRef] 
30. Corry, J.; Poon, W.; McPhee, N.; Milner, A.D.; Cruickshank, D.; Porceddu, S.V.; Rischin, D.; Peters, L.J. Randomized study of percutaneous endoscopic gastrostomy versus nasogastric tubes for enteral feeding in head and neck cancer patients treated with (chemo)radiation. J. Med. Imaging. Radiat. Oncol. 2008, 52, 503-510. [CrossRef]

31. Sadasivan, A.; Faizal, B.; Kumar, M. Nasogastric and percutaneous endoscopic gastrostomy tube use in advanced head and neck cancer patients: A comparative study. J. Pain Palliat. Care Pharmacother. 2012, 26, 226-232. [CrossRef]

32. Silander, E.; Nyman, J.; Bove, M.; Johansson, L.; Larsson, S.; Hammerlid, E. Impact of prophylactic percutaneous endoscopic gastrostomy on malnutrition and quality of life in patients with head and neck cancer: A randomized study. Head Neck 2012, 34, 1-9. [CrossRef]

33. Silander, E.; Jacobsson, I.; Bertéus-Forslund, H.; Hammerlid, E. Energy intake and sources of nutritional support in patients with head and neck cancer-A randomised longitudinal study. Eur. J. Clin. Nutr. 2013, 67, 47-52. [CrossRef] [PubMed]

34. Axelsson, L.; Silander, E.; Nyman, J.; Bove, M.; Johansson, L.; Hammerlid, E. Effect of prophylactic percutaneous endoscopic gastrostomy tube on swallowing in advanced head and neck cancer: A randomized controlled study. Head Neck 2017, 39, 908-915. [CrossRef] [PubMed]

35. Bowrey, D.J.; Baker, M.; Halliday, V.; Thomas, A.L.; Pulikottil-Jacob, R.; Smith, K.; Morris, T.; Ring, A. A randomised controlled trial of six weeks of home enteral nutrition versus standard care after oesophagectomy or total gastrectomy for cancer: Report on a pilot and feasibility study. Trials 2015, 21, 531. [CrossRef] [PubMed]

36. Baker, J.; Janda, M.; Graves, N.; Bauer, J.; Banks, M.; Garrett, A.; Chetty, N.; Crandon, A.J.; Land, R.; Nascimento, M.; et al. Quality of life after early enteral feeding versus standard care for proven or suspected advanced epithelial ovarian cancer: Results from a randomised trial. Gynecol. Oncol. 2015, 137, 516-522. [CrossRef] [PubMed]

37. Li, J.H.; Han, L.; Du, T.P.; Guo, M.J. The effect of low-nitrogen and low-calorie parenteral nutrition combined with enteral nutrition on inflammatory cytokines and immune functions in patients with gastric cancer: A double blind placebo trial. Eur. Rev. Med. Pharmacol. Sci. 2015, 19, 1345-1350. [PubMed]

38. Gavazzi, C.; Colatruglio, S.; Valoriani, F.; Mazzaferro, V.; Sabbatini, A.; Biffi, R.; Mariani, L.; Miceli, R. Impact of home enteral nutrition in malnourished patients with upper gastrointestinal cancer: A multicentre randomised clinical trial. Eur. J. Cancer 2016, 64, 107-112. [CrossRef] [PubMed]

39. Froghi, F.; Sanders, G.; Berrisford, R.; Wheatley, T.; Peyser, P.; Rahamim, J.; Lewis, S. A randomised trial of post-discharge enteral feeding following surgical resection of an upper gastrointestinal malignancy. Clin. Nutr. 2017, 36, 1516-1519. [CrossRef] [PubMed]

40. Wu, W.; Zhong, M.; Zhu, D.M.; Song, J.Q.; Huang, J.F.; Wang, Q.; Tan, L.J. Effect of Early Full-Calorie Nutrition Support Following Esophagectomy: A Randomized Controlled Trial. JPEN J. Parenter. Enteral. Nutr. 2017, 41, 1146-1154. [CrossRef]

41. Brown, T.E.; Banks, M.D.; Hughes, B.G.M.; Lin, C.Y.; Kenny, L.M.; Bauer, J.D. Randomised controlled trial of early prophylactic feeding vs standard care in patients with head and neck cancer. Br. J. Cancer 2017, 117, 15-24. [CrossRef] [PubMed]

42. Kaźmierczak-Siedlecka, K.; Folwarski, M.; Ruszkowski, J.; Skonieczna-Żydecka, K.; Szafrański, W.; Makarewicz, W. Effects of 4 weeks of Lactobacillus plantarum $299 \mathrm{v}$ supplementation on nutritional status, enteral nutrition tolerance, and quality of life in cancer patients receiving home enteral nutrition-A double-blind, randomized, and placebo-controlled trial. Eur. Rev. Med. Pharmacol. Sci. 2020, 24, 9684-9694. [CrossRef] [PubMed]

43. Liu, K.; Ji, S.; Xu, Y.; Diao, Q.; Shao, C.; Luo, J.; Zhu, Y.; Jiang, Z.; Diao, Y.; Cong, Z.; et al. Safety, feasibility, and effect of an enhanced nutritional support pathway including extended preoperative and home enteral nutrition in patients undergoing enhanced recovery after esophagectomy: A pilot randomized clinical trial. Dis. Esophagus 2020, 33, doz030. [CrossRef]

44. Arruebo, M.; Vilaboa, N.; Sáez-Gutierrez, B.; Lambea, J.; Tres, A.; Valladares, M.; González-Fernández, A. Assessment of the evolution of cancer treatment therapies. Cancers 2011, 3, 3279-3330. [CrossRef]

45. Meyer, A.C.; Drefahl, S.; Ahlbom, A.; Lambe, M.; Modig, K. Trends in life expectancy: Did the gap between the healthy and the ill widen or close? BMC Med. 2020, 18, 41. [CrossRef]

46. Gayatri, D.; Efremov, L.; Kantelhardt, E.J.; Mikolajczyk, R. Quality of life of cancer patients at palliative care units in developing countries: Systematic review of the published literature. Qual. Life Res. 2021, 30, 315-343. [CrossRef]

47. Lis, C.G.; Gupta, D.; Lammersfeld, C.A.; Markman, M.; Vashi, P.G. Role of nutritional status in predicting quality of life outcomes in cancer-A systematic review of the epidemiological literature. Nutr. J. 2012, 11, 27. [CrossRef]

48. Muscaritoli, M.; Arends, J.; Bachmann, P.; Baracos, V.; Barthelemy, N.; Bertz, H.; Bozzetti, F.; Hütterer, E.; Isenring, E.; Kaasa, S.; et al. ESPEN practical guideline: Clinical Nutrition in cancer. Clin. Nutr. 2021, 40, 2898-2913. [CrossRef] [PubMed]

49. Wanden-Berghe, C.; Patino-Alonso, M.C.; Galindo-Villardón, P.; Sanz-Valero, J. Complications Associated with Enteral Nutrition: CAFANE Study. Nutrients 2019, 11, 2041. [CrossRef] [PubMed]

50. Schell, R.F.; Sidone, B.J.; Caron, W.P.; Walsh, M.D.; White, T.F.; Zamboni, B.A.; Ramanathan, R.K.; Zamboni, W.C. Meta-analysis of inter-patient pharmacokinetic variability of liposomal and non-liposomal anticancer agents. Nanomedicine 2014, 10, 109-117. [CrossRef]

51. Pandey, M.; Singh, S.P.; Behere, P.B.; Roy, S.K.; Singh, S.; Shukla, V.K. Quality of life in patients with early and advanced carcinoma of the breast. Eur. J. Surg. Oncol. 2000, 26, 20-24. [CrossRef] [PubMed]

52. Ringdal, G.I.; Ringdal, K. A follow-up study of the quality of life in cancer patients with different prognoses. Qual. Life Res. 2000, 9, 65-73. [CrossRef] 
53. Salas, S.; Mercier, S.; Moheng, B.; Olivet, S.; Garcia, M.E.; Hamon, S.; Sibertin-Blanc, C.; Duffaud, F.; Auquier, P.; Baumstarck, K. Nutritional status and quality of life of cancer patients needing exclusive chemotherapy: A longitudinal study. Health Qual. Life Outcomes 2017, 15, 85. [CrossRef]

54. Lakusta, C.M.; Atkinson, M.J.; Robinson, J.W.; Nation, J.; Taenzer, P.A.; Campo, M.G. Quality of life in ovarian cancer patients receiving chemotherapy. Gynecol. Oncol. 2001, 81, 490-495. [CrossRef]

55. Wang, L.; Wang, X.; Wang, X. The effectiveness of enteral nutrition for patients with primary liver cancer: A randomized controlled study protocol. Medicine 2021, 100, e23973. [CrossRef] [PubMed]

56. Fietkau, R.; Lewitzki, V.; Kuhnt, T.; Hölscher, T.; Hess, C.F.; Berger, B.; Wiegel, T.; Rödel, C.; Niewald, M.; Hermann, R.M.; et al. A disease-specific enteral nutrition formula improves nutritional status and functional performance in patients with head and neck and esophageal cancer undergoing chemoradiotherapy: Results of a randomized, controlled, multicenter trial. Cancer 2013, 119, 3343-3353. [CrossRef] [PubMed] 